УДК 94:579(477)«185/195»(092)

\section{Костенко Оксана,}

кандидат історичних наук, доцент

кафедри загальної історії, правознавства і

методик навчання

dpu.kaf.istorii@gmail.com

https://orcid.org/0000-0003-0831-9158

Державний вищий навчальний заклад «Переяслав-Хмельницький державний педагогічний університет імені Григорія Сковороди», вул. Сухомлинського, 30, м. Переяслав-Хмельницький, Київська обл., Україна, 08401

\section{Сіропол Володимир,}

кандидат історичних наук, доцент

кафедри загальної історії, правознавства i

методик навчання

dpu.kaf.istorii@gmail.com

https://orcid.org/0000-0001-6069-2609

Researcher ID: U-8091-2018

Державний вищий навчальний заклад «Переяслав-Хмельницький державний педагогічний університет імені Григорія Сковороди», вул. Сухомлинського, 30, м. Переяслав-Хмельницький, Київська обл., Україна, 08401

\section{DOI https://doi.org/10.31470/2415-3567- 2019-46-147-155}

\section{Kostenko Oksana,}

Candidate of Historical Sciences, Assistant Professor of General History, Science of Law, Teaching Methods Department dpu.kaf.istorii@gmail.com https://orcid.org/0000-0003-0831-9158

Pereiaslav-Khmelnytskyi Hryhorii Skovoroda State Pedagogical University, 30, Sukhomlynsky Str.,

Pereiaslav-Khmelnytskyi, Kyiv region, Ukraine, 08401

\section{Siropol Volodymyr,}

Candidate of Historical Sciences, Assistant Professor of General History, Science of Law, Teaching Methods Department dpu.kaf.istorii@gmail.com https://orcid.org/0000-0001-6069-2609

Researcher ID: U-8091-2018

Pereiaslav-Khmelnytskyi Hryhorii Skovoroda State Pedagogical University, 30, Sukhomlynsky Str., Pereiaslav-Khmelnytskyi, Kyiv region, Ukraine, 08401

\title{
А.В. КРАЇНСЬКИЙ ТА ЙОГО ВНЕСОК У РОЗВИТОК МІКРОБІОЛОГЇ̈
}

У статті йдеться про життєвий і творчий шлях одного з провідних учених у галузі мікробіологї Андрія Васильовича Країнського у першій чверті XX cm. Його праці поглибили знання у сфері мікрофлори трунтів. Андрій Васильович виконав і надрукував низку експериментальних досліджень над різними групами трунтових мікробів. Головними питаннями, щьо розробив А. Краӥнський, $\epsilon$ питання засвоєння атмосферного азоту мікроорганізмами, а також збагачення трунту азотом $i$ вивчення життєдіяльності актиномічетів у трунті. А. Краӥнський виділив $і$ вивчив активність азотобактера в дев'ятьох трунтових різновидах Украӥни. Він був першим ученим, щуо відкрив цүілющі антибіотичні властивості грибка «Actinomyces griseus».

Крім наукової діяльності вчений також присвятив багато часу суспільній праці. Зокрема, займався питаннями аграрної освіти. Під його егідою разом з однодумиями було створено Київське агрономічне товариство. А. Краӥнський відстоював розширення викладання сільськогосподарського курсу при університетах, щуо розгорнулося в межах товариства в 1911 р. Констатовано, щзо за короткий час свого життя вчений приніс славу Університету св. Володимира в новому тоді напрямі науки - сільськогосподарській мікробіологіі. Багато сил доклав до поширення наукових знань, відстоював пропозииіі розширення викладання сільськогосподарських предметів у межах університету.

Ключові слова: мікробіологія, А. Краӥнський, товариство, розвиток, наука, 
університет, освіта.

\section{ANDRIY KRAINSKYI AND ITS CONTRIBUTION TO THE DEVELOPMENT OF MICROBIOLOGY}

This article deals with Andriy Krainskyi's professional life and accomplishments in the field of microbiology. His scholarly articles and scientific work helped to deepen the knowledge and understanding of the soil structure. Andriy Krainskyi conducted and published numerous studies and experiments on the different types of soil microbes. Thanks to these experiments, he became an outstanding scientist in Ukraine and abroad. The main topics of his research were the absorption of nitrogen by soil and by microorganisms, and the research on the actinomycetes in the soil. Furthermore, in his works, Andriy Krainskyi highlighted the influence of the azotobacterin in nine soil types in Ukraine. He was the first researcher who revealed the healing antibiotic properties of Actinomyces griseus.

Moreover, Andriy Krainskyi made a significant contribution not only to science but also to social work. He was engaged in the field of agriculture studies. He and his colleagues founded the Kyiv Agriculture Society. Andriy Krainskyi suggested that agricultural sciences should be part of university curriculums and education. It is stated that in a short time of his life the scientist brought glory to the University of St. Vladimir in the new then direction of science agricultural microbiology. Many forces have contributed to the dissemination of scientific knowledge, supported the proposal to expand the teaching of agricultural subjects within the university.

Keywords: microbiology, Andriy Krainskyi, society, development, science, university, education.

У наш час, час стрімкого розвитку новітніх технологій та індустріалізації з кожним днем зростають потреби людства. Зокрема, воно подає запит до найбільш гострих, актуальних і нагальних питань, вирішення яких вимагає від нас мобілізації наукових зусиль. Одними з них є підняття якості медицини, харчування, агрономії, виноробства тощо. Провідне місце тут посідає саме мікробіологія. Вивчення іiі досвіду дозволить нам якомога швидше реагувати на виклики, які стоять сьогодні перед нами. Тому цілком зрозумілим і актуальним $є$ аналіз іï основних здобутків, зокрема, одного 3 відомих фахівців цієї галузі А.В. Країнського.

Мікробіологія - наука, яка набула остаточного визнання самостійної дисциплін в системі університетських наук лише на початку XX ст.

Перші основи мікробіології заклав Левенгук в середині XVIII ст., проте до кінця першої половини XIX ст. про фізіологію мікробів та біохімічні явища, що пов'язувалися б 3 морфологією мікроорганізмів, тривалий час не було майже ніяких наукових розвідок. Опублікування основних праць Пастера (1855-1865) сприяло бурхливому розвитку цієї науки [13, с. 373]. Спираючись на розроблену Пастером і вдосконалену Кохом раціональну методику, виходячи 3 представленої цими геніальними дослідниками концепції ролі мікробів як збудників шумувань та інфекційних захворювань, мікробіологія переможно розв'язує одну за однією найважливіші проблеми і в останній чверті XIX ст. набуває значення самостійної науки величезної теоретичної і практичної ваги [17, с. 93]. Наприкінці XIX ст. мікробіологія почала розвиватися як самостійна наукова галузь. Ця нова галузь природничо-історичних наук дуже вплинула на розвиток прикладних наук, зокрема, виноробства, пивоваріння, що базувалися на результатах досліджень у мікробіології. Визнання провідної іiі ролі в медицині, техніці, агрономії починало охоплювати все ширші кола, що позначилося заснуванням мікробіологічних кафедр в університетах. Осередками наукової роботи в цій галузі були, в основному, кафедри бактеріології при медичних факультетах.

Так, в Університеті св. Володимира, перш за все, отримала розвиток медична 
мікробіологія, чому сприяла лабораторія О.Д. Павловського, заснована на медичному факультеті [13, с. 373]. У другій половині XIX ст. деякі професори природничого відділення (О.В. Баранецький, І.Г. Борщов) у своїх працях приділяли увагу питанням, пов'язаним 3 мікробіологією. За спогадами випускників природничого відділення, професор О.В. Баранецький у курсі фізіології рослин, який він читав на природничому факультеті впродовж 30 років (1873-1903), завжди приділяв належну увагу мікроорганізмам і ретельно стежив за розвитком цієї науки [17, с. 95$]$.

Питання сільськогосподарської мікробіології були найбільше розкриті в дослідженнях приват-доцента А.В. Країнського, що працював в агрономічній лабораторії, якою тоді керував проф. С.М. Богданов.

А.В. Країнський народився в 1878 р. в м. Шебекіно Курської області в родині відомого в ті часи вченого-агронома Василя Свграфовича Країнського, який багато працював на Харківщині. Після закінчення гімназії в Харкові Андрій Васильович вступив до Київського університету. У 1903 р. він закінчив природниче відділення фізикоматематичного факультету Університету св. Володимира, одержавши диплом першого ступеня.

Будучи студентом третього курсу, А.В. Країнський почав працювати над проблемами агрономічної хімії. На п’ятому курсі, зацікавившись працями Тімірязєва, Костичева, Вільямса, Прянишникова та інших видатних учених кінця ХIX ст., він займається вивченням кругообігу азоту в природі. Особливо його цікавила роль азотозасвоюваних організмів у збагаченні азотом грунту. 31902 р. студент А. Країнський опановує техніку мікробіологічного аналізу в лабораторії професора О.Д. Павловського [3, с. 766]. Ознайомившись із мікробіологічною методикою в лабораторії професора Павловського, А. Країнський поставив своїм завданням глибше дослідити роль грунтової мікрофлори як одного із чинників родючості грунтів.

У 1904 р. А. Країнського було затверджено на посаді позаштатного лаборанта Університету при агрономічній лабораторії [10, с. 10]. Перші праці А.В. Країнського присвячені проблемі фіксації атмосферного азоту грунтом в аеробних умовах. Головним об'єктом його дослідів був Azotobacter chroocosum. Крім того, дослідник перевірив і підтвердив дані К.А. Пурієвича щодо засвоєння вільного азоту цвілевими грибками [17, с. 99].

У 1904-1905 pр. А.В. Країнський перебував на дійсній військовій службі в 68-й артилерійській бригаді м. Курська. Після звільнення в запас повернувся до наукової праці в університеті, продовжує розпочаті дослідження.

Ще в 1908 р. А. Країнський відзначив, що азотобактер має властивість виділяти ензими і добре розвивається в присутності вуглеводів, інсуліну і, особливо, крохмалю, оцукровуючи їх. А. Країнський експериментально довів, що азотобактер може використовувати різні джерела вуглецевого харчування. У працях ученого закладені основи застосування азотобактера як речовини для удобрювання полів [1, с. 7].

Наслідки досліджень А. Країнського з цієї дуже важливої з практичного погляду проблеми подані в його дисертації «Обогащение почв азотом в связи с жизнедеятельностью аэробных микроорганизмов, ассимилирующих свободный азот» [8]. Основоположною для автора є думка, що більшість попередніх дослідників методологічно неправильно підходили до цієї проблеми: ті з них, які вивчали фізіологію мікроорганізмівфіксаторів азоту, не досліджували явищ, які спричинюють ці мікроби в грунті. I навпаки, учені, що досліджували грунтові процеси фіксації азоту, не звертали уваги на фізіологію його збудників.

Ця праця вченого, за яку йому було присвоєно науковий ступень магістра агрономії, була важливим внеском у науку. Ї̈̈ автор вперше подолав методологічну помилку, що робили попередні дослідники, які, вивчаючи фізіологію мікроорганізмів-фіксаторів азоту, або не досліджували явищ, що спричинялися цими мікробами, або досліджували грунтові процеси фіксації азоту і не звертали уваги на фізіологію його збудників. А. Країнський 
вивчив вплив вологості грунту і деяких інших зовнішніх факторів на фіксацію азоту та співвідношення між кількістю засвоєного азоту в грунті та кількістю витраченого на це органічного матеріалу [17, с. 99].

Фізіологічні досліди А. Країнського показали, що Azotobacter може використовувати як джерело енергії найрізноманітніші органічні речовини, які належать до кислот, спиртів і вуглеводнів. Далі виявилося, що збільшення аерації з прискоренням оксидації цих речовин разом з тим зменшує кількість органічного матеріалу, потрібного для зв'язування одиниці вільного азоту, отже зменшує витрату енергії, потрібної для цього синтетичного процесу. У грунтах, багатих азотом, в умовах, що сприяють амоніфікації, за А. Країнським, процес фіксації атмосферного азоту не повинен виявлятися. Варто зазначити, що спроби пізніших дослідників підтвердили цей висновок.

Зі своїх дослідів А. Країнський робить і певні практичні висновки щодо значення чорного пару, культури пропашних рослин. Роботу мікробіо-фіксаторів азоту в грунті А. Країнський уявляє собі так: весною при наявності чималого запасу грунтової вологи діяльність цих мікробів розпочинається на поверхні грунту в симбіозі з водоростями. При підсиханні поверхні зона життєдіяльності фіксаторів азоту пересувається в глибину, де, можливо, азотобактер вступає в симбіоз із бактеріями, які виділяють кисень. Коли в грунті вологи надто багато, починають функціонувати анаеробні фіксатори азоту.

У 1913 р. Андрій Васильович захистив дисертацію на ступінь магістра агрономії на тему «Обогащение почв азотом в связи с жизнедеятельностью аэробных микроорганизмов, ассимилирующих свободный азот». Рецензію на наукову роботу було надано вже відомими на той час професорами університету В.В. Колкуновим та К.А. Пурієвичем [9].

В основу роботи було покладене вивчення «Azotobacter chroocosum». Ця серйозна праця була зроблена Андрієм Васильовичем самостійно, в умовах скромної агрономічної лабораторії. Фізіологічні досліди А. Країнського показали, що Azotobacter може використовувати як джерело енергії найрізноманітніші органічні речовини, які належать до кислот, спиртів і вуглеводнів. Збільшення аерації зменшує витрату енергії, потрібної для цього синтетичного процесу. На основі своїх дослідів А. Країнський дійшов висновку, що в грунтах, багатих на азот, процес фіксації атмосферного азоту не повинен виявлятися. Праці наступних дослідників підтвердили цей висновок [2, с. 151].

У 1909 р. учений був допущений до читання лекцій у Київському університеті в якості приват-доцента кафедри агрономії [10, с. 95]. У цьому ж році молодий науковець робить доповідь стосовно практичних результатів за темою основних досліджень на засіданні Товариства природознавців [7].

Необхідно проаналізувати ще одну працю вченого: «К вопросу о методах исследования микробиологических свойств почвы» [4]. У ній автор стверджує, що звичайний облік грунтових мікробів за кількістю колоній, що виросли в тому чи іншому середовищі, ніяк не може слугувати показником інтенсивності мікробіологічних процесів у грунті. Цей метод, на думку автора, міг би бути корисним тільки в тому випадку, коли б ми мали змогу підраховувати певні фізіологічні групи мікроорганізмів безпосередньо в грунті або коли б знайшли спосіб попереднього відокремлення активних клітин від неактивних. Критично ставиться автор і до методу Ремі. Прихильникам його, каже він, треба було б передусім перевірити, чи існує паралелізм між процесами, що відбуваються в грунті і в штучному середовищі.

Із пізніше опублікованих праць А. Країнського варта аналізу його стаття «К вопросу о разрушении клетчатки микроорганизмами», де він описує свої досліди з аеробними мікробами, збудниками цього процесу [5]. Ця робота А. Країнського була присвячена вивченню актиноміцетів.

3 метою підготуватися грунтовніше до роботи в цьому напрямі А. Країнський їде в Голландію, у Дельфт. У 1912 р. він одержує відрядження в Голландію, де працює в лабораторії одного з найвидатніших мікробіологів початку XX ст. Байєрінка. Повернувши 
в 1914 р. до Києва, Андрій Васильович написав працю про властивості актиноміцетів. Результати своїх досліджень про значення актиноміцетів у природі викладені автором в останній його публікації німецькою мовою: «Die Actinomyceten u ihre Bedentung in der Natur», що вийшла в «Centrallblat f. Bateriologie» 41, 649, 1914 р. У цій статті вчений дає досить повний огляд усього, що було відомо на той час про морфологію, фізіологію, систематику та екологію актиноміцетів, поповнюючи ці відомості численними даними 3 власних спостережень i спроб. Вивчаючи питання руйнування целюлози мікроорганізмами, А. Країнський встановив, що ця здатність властива в значній мірі актиноміцетам. Досить указати, що тут він описує 14 нових видів із цієї групи мікроорганізмів, які згодом увійшли у відому монографію актиноміцетів, видану Р. Ліске в 1920 р. У ній вчений у числі інших актиноміцетів описав вивчений ним «Actinomyces griseus» - продуцент стрептоміцину.

Треба відзначити, що дальший розвиток грунтової мікробіології підтвердив цілковиту правдивість цих критичних зауважень А. Країнського. Виноградський, реформуючи цю галузь нашої науки у своїх новітніх працях (1925-1930рр.), виходив 3 аналогічних міркувань [17, с. 101].

У перше десятиріччя XX ст. центром об'єднання агрономів м. Києва була лабораторія мережі дослідних полів Всеросійського товариства цукрозаводчиків. Група передових учених-агрономів, у тому числі професорсько-викладацький склад агрономічної кафедри Університету св. Володимира, організувала Київське агрономічне товариство (КАТ), яке було першим науковим фаховим товариством в Україні. А.В. Країнский був одним з організаторів товариства, членом правління і його науковим секретарем [12, с. 24].

На засіданнях цього товариства вчений неодноразово виступав 3 науковими доповідями, що завжди викликали зацікавленість фахівців та широке обговорення. Прикладом популяризації власних досліджень можуть слугувати його доповіді: «Биологическое и техническое связывание азота» (1910) та «Микробиология в земледелии» (1912) [14; 12, с. 3].

Актуальною стосовно нашого дослідження є участь А.В. Країнського в обговоренні питання розширення викладання сільськогосподарського курсу при університетах, що розгорнулося в межах товариства в 1911 р. Полеміку викликала доповідь професора В.В. Коклунова, що на той час очолював кафедру агрономії в Київському університеті. Саме в обговоренні цієї доповіді на звинувачення С.Л. Франкфурта (відомого діяча дослідної справи) у малій науково-дослідній користі вчених та викладачів виступив А.В. Країнський. Він протестував проти огульного звинувачення російських професорів університетів у небажанні працювати. Учений запевняв, що фахівці-дослідники можуть працювати в навчальних закладах. Він говорив: «Зокрема серед професорів російських університетів немало видних учених, що користуються популярністю і за межами Росії. Уведення діячів дослідних установ в університети цілком можливо, тому що той, хто витримав магістерський іспит і прочитав 2 пробні лекції, може бути приват-доцентом» $[15$, c. 2$]$.

Проте важливість питання викликала необхідність підготовки Андрієм Васильовичем доповіді «О желательном типе агрономической школы», 3 якою він виступив 18-го березня 1911 p. [16]. У доповіді вчений визначив дві основні проблеми сільськогосподарської освіти того часу: по-перше, завдання, які стояли перед випускником - фахівцем з агрономії; по-друге, завдання вищої фахової школи. Зокрема він наголошував, що «перед агрономами ставилося завдання складання організаційного плану господарств. Для цього фахівець повинний був уміти розібратися в економічних умовах, оцінити умови ринку, шляхів сполучення та інше; розібратися в природничоісторичних умовах місцевості; добре знати основи сільськогосподарської техніки» [16, c. 2].

Щодо визначення завдань вищої фахової школи він вказував, що «вища 
сільськогосподарська школа повинна володіти відомого роду науковою традицією, вона повинна мати можливість науково працювати, мати запас осіб, що готуються до наукової діяльності, які, пройшовши встановлений [природничий] курс, доповнюють [знання] основними [агрономічними] курсами» $[16$, с. 8$]$.

Доповідь ученого викликала жорсткі суперечки, у яких брали участь А.М. Левшин, О.К. Филиповський, Т.В. Лікоть, О.І. Душечкін, М.М. Каган, I.В. Бельговський та С.Ф. Веселовський.

Зокрема, С. Веселовський як представник Київського політехнічного інституту вважав, що «школа повинна бути єдиною, вона повинна бути пов'язана 3 районом». Стосовно Києва він вважав непотрібним відкриття агрономічного відділення при університеті у зв'язку з наявністю сільськогосподарського відділення при КПІ.

У відповідь А.В. Країнський доводив, що «в університеті агрономія існувала значно раніше, ніж був організований політехнічний інститут. Було б доцільно знищити університетську агрономію, якби вона не виявляла життєздатності. Дійсність показує, що, не дивлячись на самі несприятливі умови, агрономія в Київському університеті не тільки не схильна вмирати, але навпаки, виявляє тенденцію до розвитку і працює досить продуктивно. Шкоди відділення [при університеті] не принесе у зв'язку з величезною потребою краю в агрономічних силах» [16, с. 9].

За результатами обговорення доповіді А.В. Країнського «О желательном типе агрономической школы» збори прийняли таку резолюцію: «Визнаючи найкращим типом вищої агрономічної школи школу університетську за духом, яке б не було їі найменування, Київське агрономічне товариство визнає бажаним влаштування агрономічного відділення при університеті» [11, с. 3].

Таким чином, необхідно підсумувати, що, крім науково-педагогічної роботи, Андрій Васильович Країнський вів широку суспільну роботу, сприяючи поширенню сільськогосподарської освіти та відстоюючи право університету на розширення викладання сільського господарства в його межах.

Талановитий київський мікробіолог співпрацював із загальноросійськими виданнями. Так, він був співробітником «Журнала Опытной Агрономии», для якого готував реферати найактуальніших вітчизняних та зарубіжних статей 3 агрономії та грунтознавства. Крім того, учений не раз виступав і в загально-агрономічній пресі 3 публіцистичними статтями широко змісту. У журналі «Хозяйство» за 1911 р. була надрукована його стаття «Биологическое и техническое связывание азота», за 1912 р. популярна стаття «Микробиология в земледелии», де вчений указував на величезне значення цієї науки для теорії родючості грунту, але разом 3 тим підкреслював, що практична іiі вага в землеробстві досі зовсім мізерна [6; 14]. Керувати грунтовими процесами, на думку автора, землероби зможуть тільки тоді, коли навчаться регулювати діяльність певних фізіологічних груп мікробів, чого можна досягти, наприклад, вносячи у грунт специфічні речовини (антисептики тощо). А.В. Країнський працював над проблемою введення в землеробство спеціальних бактеріологічних прийомів. Одним із перших прийомів було «зараження грунтів культурами клубенькових бактерій». Автор сподівався, що незабаром будуть знайдені специфічні речовини, які знищуватимуть або сприятимуть послабленню визначених фізіологічних груп мікроорганізмів. У такому випадку з'явиться можливість впливати на грунтові процеси в бажаному спрограмованому напрямі. Учений одним із перших в Україні вказував на величезне значення мікробіології в теорії родючості грунту.

За короткий час (з 1908 р. до 1914 р.) Андрій Васильович виконав і надрукував низку експериментальних досліджень над різними групами грунтових мікробів. Ці дослідження звернули на нього увагу як на видатного мікробіолога не лише в нас, а й за кордоном. Головними питаннями, що розробив А. Країнський, є питання засвоєння атмосферного азоту мікроорганізмами, а також збагачення грунту азотом і вивчення життєдіяльності актиноміцетів у грунті. А. Країнський виділив і вивчив активність азотобактера в 
дев'ятьох грунтових різновидах України. Він був першим ученим, що відкрив цілющі антибіотичні властивості грибка «Actinomyces griseus».

А.В. Країнський загинув від перніціозної анемії. У періоди ремісії хвороби продовжував роботу над актиноміцетами. Це була людина високого інтелекту, що любила науку, захоплювалася ідеями вітчизняної школи біологів-грунтознавців. За короткий час свого життя вчений приніс славу Університету св. Володимира в новому тоді напрямі науки - сільськогосподарській мікробіології. Багато сил доклав до поширення наукових знань, відстоював пропозиції розширення викладання сільськогосподарських предметів у межах університету.

\section{ДЖЕРЕЛА ТА ЛІТЕРАТУРА}

1. Власюк П.А. Содружество русских и украинских ученых // Земледелие. 1954. №5. C.3-12.

2. Історія Київського університету. 1834-1959. Київ: Вид-во Київського ун-ту, 1959. $629 \mathrm{c}$.

3. Карышева К.А. Андрей Васильевич Краинский (130 лет со дня рождения) // Врачебное дело. 1958. №7. С. 766.

4. Краинский А.В. К вопросу о методах исследования микробиологических свойств почвы // Журнал опытной агрономии. 1909. Т. Х. №3. С.39-47.

5. Краинский А.В. К вопросу о разрушении клетчатки микроорганизмами // Журнал опытной агрономии. 1913. T.XIV. С.253-261.

6. Краинский А.В. Микробиология в земледелии // Хозяйство. 1912. С. 988-995.

7. Краинский А.В. О выделении из почв Киевской и Черниговской губ. Azotobacter chroocosum // Протоколы І-го (годичного) собрания Киевского общества естествоиспытателей, 25 января 1909 г. Киев, 1909. C. LXXX-LXXVI.

8. Краинский А.В. Обогащение почв азотом в связи с жизнедеятельностью аэробных микроорганизмов, усваивающих свободный азот // Университетские известия. 1912., неофиц. ч. №.4 С.1-58; № 8. С.59-132; № 9. С.133-182, I-II.

9. Краинский А.В. Обогащение почв азотом в связи с жизнедеятельностью аэробных микроорганизмов, ассимилирующих свободный азот. Рец.: В. Колкунов и К. Пуриевич // Университетские известия. 1912., №12, офиц. ч. С.1-3.

10.Личный состав Университета св. Владимира к 15 августа 1904 г. // Университетские известия. 1904. №10. С.1-17. $13 \mathrm{c}$.

11.Отчет о деятельности Киевского Агрономического общества за 1911 г. [Б. м. и г.].

12. Отчет о деятельности Киевского Агрономического общества за 1912 г. Киев: Тов. «Печатня С.П. Яковлева», 1913. 31 с.

13.Природознавство в Україні до початку XX ст. в історичному, культурному та освітньому контекстах / Ю.В. Павленко, С.П. Руда, С.А. Хорошева, Ю.О. Храмов. Київ: Видав. дім «Академперіодика», 2001. 420 с.

14.Протокол 10-го общего собрания Киевского агрономического общества, состоявшегося 10-го декабря 1910 г. // Доклады и протоколы общих собраний Киевского агрономического общества. Киев: Тип. Т.Г. Мейнандера, 1911. С.1-14.

15.Протокол 2-го Общего Собрания Киевского Агрономического Общества, состоявшегося 9-го февраля 1911 г. // Доклады и протоколы общих собраний Киевского агрономического общества. Киев: Тип. Т.Г. Мейнандера, 1912. С.1-4.

16.Протокол 6-го общего собрания Киевского Агрономического Общества, состоявшегося 18-го марта 1911 г. // Доклады и протоколы общих собраний Киевского агрономического общества. Киев: Тип. Т.Г. Мейнандера, 1912. С.1-9.

17.Холодний М.Г. До історії мікробіології в Київському університеті // Розвиток 
науки в Київському університеті за сто років. Київ: Вид-во Київ. держ. ун-ту, 1935. С.93104.

\section{REFERENCES}

1. Vlasiuk, P.A. (1954). Sodruzhestvo russkih i ukrainskih uchenyih [Commonwealth of Russian and Ukrainian scientists]. Zemledelie - Agriculture, 5, 3-12 [in Russian].

2. (1959). Istoriia Kyivskoho universytetu. 1834-1959 [History of Kyiv University]. Kyiv: Vyd-vo Kyivskoho un-tu [in Ukrainian].

3. Karyisheva, K.A. (1958). Andrey Vasilevich Krainskiy (130 let so dnya rozhdeniya) [Andrei Vasilievich Krainsky (130 years since his birth)]. Vrachebnoe delo-Medical practice, 7, 766 [in Russian].

4. Krainskiy, A.V. (1909). K voprosu o metodah issledovaniya mikrobiologicheskih svoystv pochvyi [To the question of methods for studying the microbiological properties of soil]. Zhurnal opyitnoy agronomii - Journal of Experimental Agronomy, Vols.10, 39-47 [in Russian].

5. Krainskiy, A.V. (1913). K voprosu o razrushenii kletchatki mikroorganizmami [On the destruction of fiber by microorganisms]. Zhurnal opyitnoy agronomii - Journal of Experimental Agronomy, Vols.14, 253-261 [in Russian].

6. Krainskiy, A.V. (1912). Mikrobiologiya v zemledelii [Microbiology in agriculture]. Hozyaystvo - The economy, 988-995 [in Russian].

7. Krainskiy, A.V. (1909). O vyidelenii iz pochv Kievskoy i Chernigovskoy gub. Azotobacter chroocosum [About isolation from the soils of Kiev and Chernigov lips. Azotobacter chroocosum]. Protokolyi I-go (godichnogo) sobraniya Kievskogo obschestva estestvoispyitateley - Minutes of the 1st (annual) meeting of the Kiev Society of Naturalists, LXXX-LXXVI [in Russian].

8. Krainskiy, A.V. (1912). Obogaschenie pochv azotom v svyazi s zhiznedeyatelnostyu aerobnyih mikroorganizmov, usvaivayuschih svobodnyiy azot. Universitetskie izvestiya [Soil enrichment with nitrogen in connection with the activity of aerobic microorganisms that absorb free nitrogen]. Universitetskie izvestiya - University News, 4, 1-58; 8, 59-132; 9, 133-182 [in Russian].

9. Krainskiy, A.V. (1912). Obogaschenie pochv azotom v svyazi s zhiznedeyatelnostyu aerobnyih mikroorganizmov, assimiliruyuschih svobodnyiy azot. Rets.: V. Kolkunov i K. Purievich [Soil enrichment with nitrogen in connection with the life of aerobic microorganisms that assimilate free nitrogen]. Universitetskie izvestiya - University News, 12, 1-3 [in Russian].

10. (1904). Lichnyiy sostav Universiteta sv. Vladimira k 15 avgusta $1904 \mathrm{~g}$. [The staff of the University of St. Vladimir by August 15, 1904]. Universitetskie izvestiya - University News, 10, 1-17 [in Russian].

11. Otchet o deyatelnosti Kievskogo Agronomicheskogo obschestva za 1911 g [Report on the activities of the Kiev Agronomical Society for 1911] [in Russian].

12. (1913). Otchet o deyatelnosti Kievskogo Agronomicheskogo obschestva za $1912 \mathrm{~g}$ [Report on the activities of the Kiev Agronomical Society for 1912]. Kyiv: Tov. «Pechatnya S.P. Yakovleva», 31 [in Russian].

13. Pavlenko, Yu.V., Ruda, S.P., Khorosheva, S.A. \& Khramov, Yu.O. (2001). Prirodoznavstvo $v$ Ukrayini do pochatku XX st. $v$ istorichnomu, kulturnomu ta osvitnomu kontekstah [Natural science in Ukraine until the beginning of the twentieth century. in historical, cultural and educational contexts]. Kyiv: Vidavnichiy dim «Akademperiodika» [in Ukrainian].

14. (1911). Protokol 10-go obschego sobraniya Kievskogo agronomicheskogo obschestva, sostoyavshegosya 10-go dekabrya $1910 \mathrm{~g}$. [Protocol of the 10th general meeting of the Kiev Agronomic Society, held on December 10, 1910]. Dokladyi i protokolyi obschih sobraniy Kievskogo agronomicheskogo obschestva - Reports and minutes of general meetings of the Kiev Agronomic Society. Kyiv: Tip. T.G. Meynandera, 1-14 [in Russian].

15. (1912). Protokol 2-go obschego sobraniya Kievskogo agronomicheskogo obschestva, sostoyavshegosya 9-go fevralya $1911 \mathrm{~g}$. [Protocol of the 2 nd general meeting of the Kiev 
Agronomic Society, held on February 9, 1911]. Dokladyi $i$ protokolyi obschih sobraniy Kievskogo agronomicheskogo obschestva-Reports and minutes of general meetings of the Kiev Agronomic Society. Kyiv: Tip. T.G. Meynandera, 1-4 [in Russian].

16. (1912). Protokol 6-go obschego sobraniya Kievskogo agronomicheskogo obschestva, sostoyavshegosya 18-go marta $1911 \mathrm{~g}$. [Protocol of the 6th general meeting of the Kiev Agronomic Society, held on March 18, 1911]. Dokladyi i protokolyi obschih sobraniy Kievskogo agronomicheskogo obschestva - Reports and minutes of general meetings of the Kiev Agronomic Society. Kyiv: Tip. T.G. Meynandera, 1-19 [in Russian].

17. Kholodnyi, M.H. (1935). Do istorii mikrobiolohii v Kyivskomu universyteti. [On the history of microbiology at the University of Kiev]. Rozvytok nauky $v$ Kyivskomu universyteti za sto rokiv - The development of science at the University of Kiev for one hundred years. Kyiv: Vyd-vo Kyiv. derzh. un-tu, 93-104 [in Ukrainian].

Одержано 18.04.2019.

УДК 94(477.53) «18/19»:633:63:061.2

\section{Якименко Микола,}

доктор історичних наук, професор кафедри гуманітарних i соціальних дисциплін

mykolaiak@ukr.net

http://orcid.org/0000-0003-3484-0764

Researcher ID: R-2371-2016

Полтавська державна аграрна академія, вул. Сковороди $1 / 3$, м. Полтава,

Україна, 03600

\section{Краснікова Оксана,}

кандидат економічних наук, доцент кафедри фінансів і кредиту

oksana.krasnikova@pdaa.edu.ua

http://orcid.org/0000-0002-1591-9613

Researcher ID: R-1874-2016

Полтавська державна аграрна академія вул. Сковороди 1/3, м. Полтава,

Україна, 03600

\section{DOI https://doi.org/10.31470/2415-3567- 2019-46-155-164}

\section{YakymenkoMykola,}

Doctor of Historical Sciences, professor of the Department Humanitarian and Social Disciplines mykolaiak@ukr.net http://orcid.org/0000-0003-3484-0764

Researcher ID: R-2371-2016

Poltava State Agrarian Academy, 1/3, Street Skovoroda, Poltava city, Ukraine, 03600

\section{Krasnikova Oksana,}

Candidate of Economic sciences, assistant professor of Department of Finance and Credit oksana.krasnikova@pdaa.edu.ua http://orcid.org/0000-0002-1591-9613 Researcher ID: R-1874-2016 Poltava State Agrarian Academy 1/3, Street Skovoroda, Poltava city, Ukraine, 03600

\section{ВПЛИВ ТЕОРЕТИКІВ І ПРАКТИКІВ ПОЛТАВСЬКОГО СІЛЬСЬКОГОСПОДАРСЬКОГО ТОВАРИСТВА НА МОДЕРНІЗАЦІЮ ГАЛУЗІ РОСЛИННИЦТВА НА РУБЕЖI ХIX-XX ст.}

У статті проаналізовано внесок Полтавського сільськогосподарського товариства y пропаганду агротехнічних знань не лише у масштабах полтавського регіону, але й далеко за його межами.

Очевидною заслугою членів товариства була організачія сільськогосподарських виставок, на яких не лише представники панівних класів, але й широкі маси 